\title{
Review of Collaboration between NMWCP and REDD+ in Supporting Sustainable Forest Management in Papua
}

\author{
Gun Mardiatmoko \\ Forestry Department, Faculty of Agriculture, Pattimura University, \\ Jalan Ir. M. Putuhena, Campus Poka, Ambon, 97233 Indonesia
}

Received November 19, 2012/Accepted March 5, 2013

\begin{abstract}
Various programs on sustainable forest-soil-water management have been developed and occasionally conducted by the Indonesian Ministry of Forestry, Ministry of Agriculture, and Ministry of Public Works under various programs. Unfortunately, the achievement of such programs were not satisfactorily. Currently, there exist 2 intersectoral initiatives called the National Movement for Water Conservation Partnership (NMWCP) that focused on water conservation and Reducing Emission from Deforestation and Forest Degradation (REDD+) that focused on emission reduction of greenhouse gasses through reducing deforestation and forest and land degradation. Both programs could be closely linked to carbon trade mechanism as a potential of gaining international financial supports. In principal and function-wise, the 2 programs were not distinct, particularly with regard to managing deforestation, forest degradation, forest-land-water conservation, and community empowerment/stakeholders. In principle, water conservation is inherent with forest function. In the other side, Papua is a vast region dominated by mountainous area comprises of many watersheds. In this regards, the need of having an Integrated Watershed Management (IWM) is inevitable. Therefore, collaboration between the 2 inter-sectoral programs could be the best solution for Papua. Through collaboration scheme, it would be possible to involve wider stakeholders and have more potential of generating international financial supports to carry out a more effective and efficient management offorest, land, and water.
\end{abstract}

Keywords: NMWCP, REDD+, watershed management, sustainable forest management

*Correspondence author, email: gum_mardi@yahoo.com, telp+62-812-4450-9130,fax+62-911322498

\section{Introduction}

Currently, the world is experiencing climate change, desertification expansion, biodiversity depletion, and widening of welfare gap in both developed and developing countries. Such global problems are associated with various forest, soil, and water degradation problems which resulted in freshwater scarcity and the need for serious concerns over water management practices as well as problems due to incompatible land management (Allan 2008). Moreover, low attention to freshwater biodiversity conservation had further cause the widespread degradation of habitat, pollution, water exploitation and regulation policy, excessive exploitation of fish, and disruption of invasive alien species (Strayer \& Dudgeon 2010). Pacheco et al. (2011) report that important transformations are underway in tropical landscapes in Latin America with implications for economic development and climate change. Landscape transformation is driven not only by national policies and markets, but also by global market dynamics associated with an increased role for transnational traders and investors.

The forest-soil-water degradation in watershed areas occurs in all provinces across Indonesia. Papua Province has the third and fourth longest rivers in Indonesia, namely the Mamberamo and Digul Rivers. Mamberamo Basin (watershed) is facing very serious threat with destruction rate reaching approximately 5 million ha. The Digul Watershed condition is also quite alarming. Papua is a region with extensive mountainous areas, hence watershed conservation is very important in supporting environmental protection. Furthermore, the relatively higher intact forest covers in Papua than any other major islands in Indonesia, high cultural diversity and local wisdoms, strong supports from local leaders to implement low carbon development, and special autonomous area, provide additional rationales for the implementation of Integrated Watershed Management (IWM). Anwar et al. (2011) stated that land use changes specifically deforestation, can affect watershed hydrological response which is closely related to deforestation and degradation of forests. These problems are associated with spatial planning and green development or low-carbon development, which must consider 3 important factors: environmental, social, and economic factors. In effort to overcome deforestation related problems and forest and water resources degradation, coordination and synergy in actions that encourage green 
developments are necessary. Keeping this in mind, this paper seeks to provide conceptual thinking on how to integrate these issues. This paper is organized through policy and literature studies with material derived from various natural resource management related information.

\section{Water Conservation Program and Reduction of Greenhouse Gas Emissions}

Various watershed forests protection programs have been implemented simultaneously by the central and regional governments through various specific ministries and/or cross-ministries programs. Such include forest-soil-water conservation programs carried out by Indonesian Ministry of Forestry, Ministry of Agriculture, and Ministry of Public Works. This program was implemented occasionally under different activity names, although essentially the goals were similar, i.e. the achievement of forest-soil-water conservation to support national development. Unfortunately, the results have apparently neither been optimal nor had achieved the expected targets due to financial constraints, lack of coordination among the ministries involved, sectoral ego, atomistic approach to problem solving, and limited skilled human resources. Such situation had been previously reviewed by Fadli (2002) with regard to Mahakam River Watershed management in East Kalimantan. He described that programs related to Mahakam Watershed were lacking integration and that there were a minimum involvement of the community. Hence, community empowerment is an integral aspect of watershed management. For instance, the upstream communities that were actively protect and conserve their surrounding forests should received incentives through compensation fund from the electricity companies located in the watershed area. Such funds could provide additional incentives to encourage community participation in long-term preservation and protection of the forests, as has been investigated by Guo et al. (2007) in Yangtze River, China. In addition, to achieve sustainable forest management, recognition and incorporation of local institutions in forest policy formulation is very important due to its high potentials for collective actions and its characteristics of general resources that are required to achieve sustainable management (Nursidah et al. 2012).

The latest government programs involving the Ministry of Public Works, Ministry of Forestry, Ministry of Agriculture, and National Development Planning Agency (Bappenas) were the National Movement on Water Conservation Partnership (NMWCP) focusing on water conservation and Reducing Emissions from Deforestation and Forest Degradation-Plus (REDD+), focusing on reducing greenhouse gas emissions through reducing deforestation and land and forest degradation, among others through restoration of degraded forests. Such restoration activity has the potential to generate external funding sources through carbon trade scheme. The 2 programs could be conducted simultaneously at similar region or landscape within the watershed region. REDD + program is a national program that is driven more by global initiatives in responding to climate change. The implementation of REDD+ program might require many efforts, which could be illustrated from previous study results. Purnomo et al. (2012) have conducted political mapping and analysis of REDD+ actors in Jambi and describe that there are various rights and interests of the local communities living in and adjacent to forests. The rights and interests of the communities must be satisfied, implying that REDD+ mechanisms would only be successful if it is implemented in collaboration with governments and related stakeholders, such as indigenous peoples, local leaders, and NGO's. Thus, in addition to REDD+ actors, other factor to be considered is the existence of indigenous community, as has been studied by Van Dam (2011) in Latin America. Corbera et al. (2011) urged the need for discussions on indigenous community rights upon their lands, forests, and carbon in REDD+ programs as carried out in Mexico, Brazil, and Costa Rica. According to Indartik et al. (2009), to create an effective REDD+ implementation, it is important to place more emphasis to the technical infrastructural aspects such as the availability of baseline data and carbon calculations technology as well as institutional aspects such as the availability of rules and regulations and adequate number and quality of human resources. Associated with distribution of benefits to indigenous community in REDD+ program, it is necessary to introduce knowledge on forestry business to the community as promoted by Tomaselli and Hajjar (2011). Moreover, Cronkleton et al. (2011) stated that their study indicate that social forestry management can be an option in the implementation of REDD+ in Mexico, Brazil, and Bolivia.

\section{Conceptual Thinking on the Integration of NMWCP and REDD+ Programs}

Understanding NMWCP and REDD+ NMWCP is the integration of act from various sectors, regions, and stakeholders in water resources management in the form of a national movement, to determine priority actions for river basins management and acceleration of the required management programs. NMWCP began with watershed improvements through land and forest rehabilitation and natural resources conservation. This movement comprised of 6 activities namely:

1 spatial planning, physical development, land and demography,

2 land and forest rehabilitation and water resources conservation,

3 control of destructive force of water,

4 water quality management and water pollution control,

5 efficient use of and water demand management, and

6 equitable, efficient and sustainable water resources utilization.

The NMWCP goal was to revitalize the balancing of hydrological cycle in the watersheds so the reliability of water resources both in quantity and quality could be controlled through the empowerment of government, business world, community, and law enforcement. The target to be achieved was to respond to the Water Decade for Life 2005-2015 and the achievement of development goals that include food security, economic improvement for poverty alleviation, and ecosystems protection. The NMWCP declaration by the President on April 28th of 2005 
should be followed with the implementation of NMWCP involving all related water resources sectors by implementing the Ministry of Public Works Regulation No. 377/PRT/M/2005 on Guidelines for the Formulation of NMWCP Implementation Work Plan and Implementation of Guideline to the Implementation of Integrated NMWCP Program as reference to various parties and the successful benchmarks of NMWCP. As a follow-up to the declaration, an Agreement on Critical Watershed Rehabilitation through Water and Land Resources Conservation between the Ministry of Forestry, Ministry of Public Works, and Ministry of Agriculture has been signed on May 9th of 2007. The agreement was intended to be an integrated efforts to synergize critical watersheds rehabilitation activities for the conservation of water and land resources (Kementerian PU 2010).

REDD+ is the Kyoto Protocol mechanism that accommodates the offsets between industrialized nations experiencing carbon debit $(\mathrm{CD})$ and countries producing carbon credits (CC). REDD+ is also a mechanism of reducing deforestation and forest destruction with the objective of reducing greenhouse gases emissions. The ultimate goal of REDD+ include:

1 reducing emissions from deforestation,

2 reducing emissions from forest degradation,

3 conserve forest/carbon stocks,

4 sustainable forest management,

5 increase carbon stock, and

6 distribution of benefits if REDD + were successfully implemented.

REDD+ program goes beyond carbon and includes improvements in governance, spatial planning, legal basis, and the management of forest management unit as well as involvement of community including gradually overcoming tenure problems. Currently, discussions on REDD + has raised optimism about the reduction of carbon emissions and deforestation in various tropical countries (Toni 2011). The emergence of REDD+ mechanism under the UNFCCC framework is designed with the goal of using financial incentives to enhance the role of forests in curbing climate change (Petkova et al. 2010).

With the approval of carbon sequestration project into Clean Development Mechanism (CDM), the United Nations Framework Convention on Climate Change (UNFCCC) is ratified in accordance with Act No. 6 of 1994 and continued with the establishment of the Ministry of Forestry Regulation No. P. 14/Menhut-II/2004 on Procedures for Afforestation and Reforestation within CDM Framework. In addition, since the implementation of COP13 in Bali, the Government of Indonesia c.q Ministry of Forestry was very keen in developing legal instruments that were directly associated with the implementation of REDD+ such as: P. 68/Menhut-II/2008, P. 30/Menhut-II/2009, and P. 36/Menhut-II/2009, as well as P. 20/Menhut-II/2012 on Implementation of Forest Carbon. With the availability of legal instruments for $\mathrm{CDM}$ and REDD+, the regional government has the opportunity and chances to implement carbon trading activities through CDM and REDD+ projects in their regions. As with NMWCP, REDD+ program was also declared by the President of the Republic of Indonesia.

Formulation of the Collaboration between NMWCP and REDD+ Papua Based on the above explanation on NMWCP and REDD+ programs, it is evident that many activities were similar in nature thus allowing the possibility of collaboration, and allow for a more focused activity with holistic approach. Such similar activities were deforestation and forest degradation, forest-soil-water conservation, community empowerment, and engagement of stakeholders. The different activities were spatial planning, control of

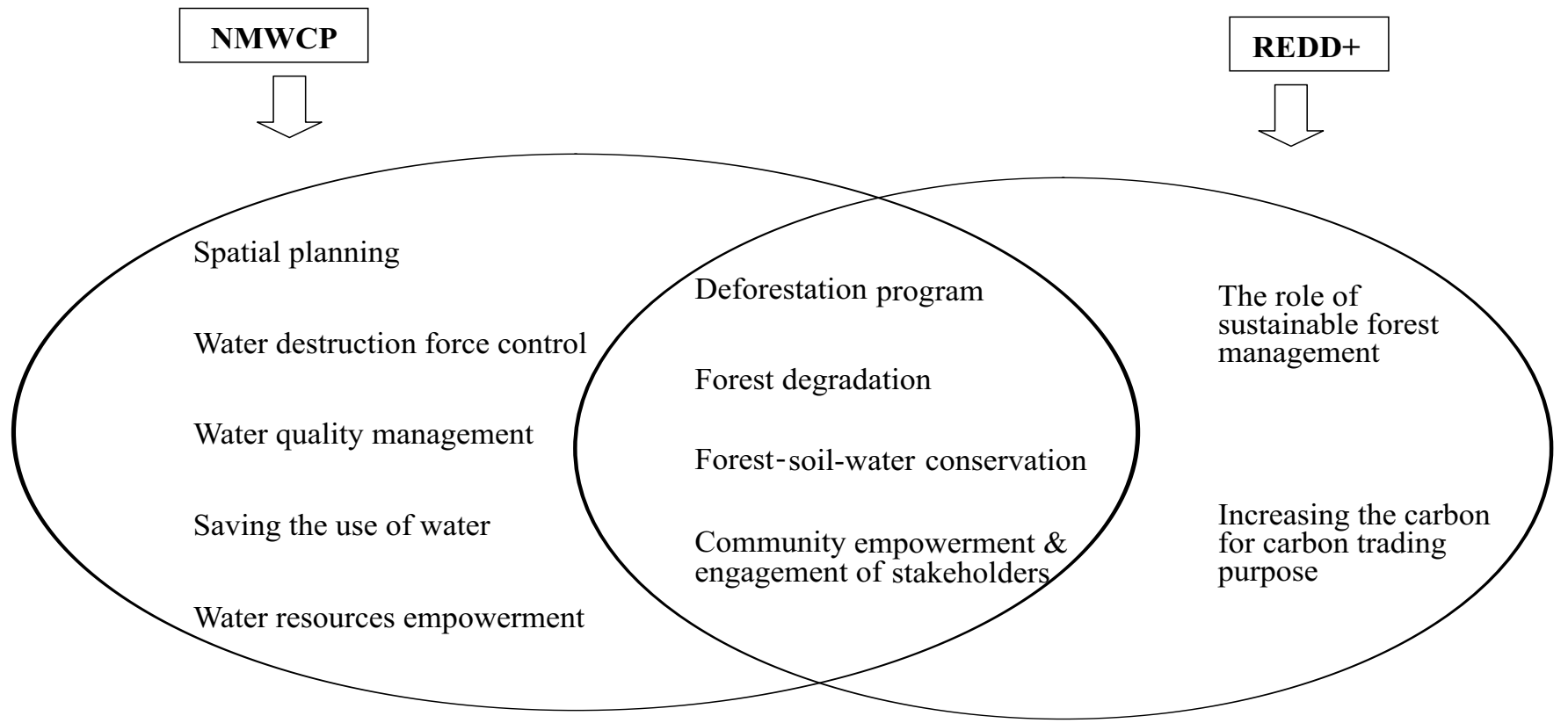

Figure 1 The collaboration between NMWCP and REDD+. 
destructive force of water, water quality management, water conservation, efficient use of water resources in NMWCP program. On REDD+ program, the different activities were role of sustainable forest management and increase of carbon for carbon trading purposes (Figure 1). In addition to the similar activities, institutionally NMWCP and REDD+ were in common, for example at the central government level, NMWCP was performed by 3 ministries, namely the Ministry of Public Works-Forestry-Agriculture while REDD+ was also implemented by Bappenas-Ministry of Forestry, and Ministry of Agriculture. Thus if the 2 programs were collaborated, then the Ministry of Forestry and the Ministry of Agriculture should be more integrated in implementing joint programs and received full support from Bappenas and the Ministry of Public Works. At regional government level, the Provincial Forestry Service and Agricultural Service should implement the program in a more integrated form and fully supported by Bappeda and the Provincial Public Works Service and so on up to the district level.

In general, NMWCP and REDD+ collaboration can be applied at different watershed regions in Indonesia, including Papua. In fact, the collaboration objective is more plausible in Papua than other provinces due to implementation of special autonomous and establishment of Papua as Demonstration Activities (DA) of REDD+ by the Central Government. In addition, the Watershed Forum has also been established in Papua Province based on the Decree of Governor of Papua No. 262 of 2006, and in West Papua Province based on the Decree of Governor of West Papua No. 87 of 2007 . Such collaboration is still in its potential state and could not be directly implemented prior to any in-depth studies involving all stakeholders. The NMWCP and REDD+ programs were highly depended on spatial planning issues that were affected by environmental, economic, and social issues, especially the tenure issue. The tenure problems in Papua were difficult to solve since there were no definite natural boundaries among ethnic territories. Consequently, resolving tenure problems in Papua should be prioritized because they were closely related to the problems of risks and benefits distribution.

The implementation of collaboration between NMWCP and REDD+ in watershed regions should be conducted in accordance to the IWM as set out in the Indonesia Government Regulation No. 37 of 2012 on Watershed Management. IWM has been carried out and assessed in some developing countries, including Bangladesh (Biswas et al. 2012), Ethiopia (Tefera \& Stroosnijder 2007), and Nepal (Achet \& Fleming 2006). The implementation of IWM in these countries was possible, particularly since community empowerments in watershed areas were carried out at various stages involving the local communities.

The collaboration concept of NMWCP and REDD+ programs should be prepared by involving all relevant stakeholders. Therefore, stakeholders identification is required among government and non-government institutions, private companies, and the communities. The information gathered should then be subsequently analyzed descriptively by presenting stakeholder mapping based on the levels of interests and influences, such as the study that was previously carried out by Sundawati and Sanudin (2009) to restore the catchment region ecosystems of Lake Toba. Formulation of the collaboration concept was undertaken through discussions, symposiums, workshops, watershed forum, and seminars as well as through the use of existing public communication forums.

\section{Conclusion}

The forest-soil-water conservation programs through NMWCP or REDD+ programs were both essentially equally important and their role was the most strategic in achieving sustainable development in Papua Region. Since functionally both programs had similar activities, i.e. dealing with deforestation, forest degradation, forest-soil-water conservation, and community/stakeholders empowerment, it would be more focused, effective and efficient if both programs were integrated. To manage similar activities, various relevant ministries should enhance their collaboration in spite of thinking their own sectoral interests. Various programs such as spatial planning, control of water degradation, water quality management, water conservation, and efficient use of water were organized by the Ministry of Public Works. Meanwhile, the role of sustainable forest management and increasing carbon/carbon trading were organized by the Ministry of Forestry, although the implementation of the policy at operation levels must be coordinated and synergized with other relevant ministries and institutions, such as the National Development Planning Agency (Bappenas), the Ministry of Agriculture, the Ministry of Environment, etc.

\section{References}

Achet SH, Fleming B. 2006. A watershed management framework for mountain areas: lessons from 25 years of watershed conservation in Nepal. Journal of Environmental Planning and Management 49(5):675694. http://dx.doi.org/10.1080/09640560600849962.

Allan A. 2008. Integrating watershed managementconnecting people to their land and water. Mountain Research and Development 28(3/4):337-338. http://dx.doi.org/10.1659/mrd.mm042.

Anwar M, Pawitan H, Multilaksono K, Jaya INS. 2011. Hydrologycal response due to deforestation in Barito Hulu Watershed, Central Kalimantan. Jurnal Manajemen Hutan Tropika17(3):119-126.

Biswas S, Vacik H, Swanson ME, Haque SMS. 2012. Evaluating integrated watershed management using multiple criteria analysis a case study at Chittagong Hill Tracts in Bangladesh. Environmental Monitoring Assessment. 184:2741-2761. http://dx.doi.org/10.1007/ s10661-011-2148-x.

Corbera E, Estrada M, May P, Navarro G, Pacheco P. 2011. Rights to land, forests and carbon in REDD+: insight from Mexico, Brazil and Costarica. Forest 2: 301-342.

Cronkleton P, Bray DB, Medina G. 2011. Community forest 
management and the emergence of multi-scale governance institutions: lesson for REDD+ development from Mexico, Brazil and Bolivia. Forest 2011(2):451-473.

Fadli A. 2002. Mengelola DAS Mahakam Secara Terpadu dan Berkelanjutan. http://timpakul.web.id/ mahakam.html [17 September 2012]

Guo Z. Li Y, Xiao X, Zhang L, Gan Y. 2007. Hydroelectricity production and forest conservation in watersheds. Ecological Applications 17:1557-1562. http://dx.doi. org/10.1890/06-0840.1.

Indartik, Djaenudin D, Ginoga KL. 2009. Faktor penentu keberhasilan implementasi pengurangan emisi dari deforestasi dan degradasi hutan: studi kasus Riau. Jurnal Penelitian Sosial dan Ekonomi Kehutanan 6(2):83-98.

Kementerian PU. 2010. Gerakan Nasional Kemitraan Penyelamatan Air http://www.bbwsso.net/sisda/ gnkpa.htm. [29 Desember 2010].

Nursidah, Nugroho B, Darusman D, Rusdiana O, Rasyid Y. 2012. Pengembangan institusi untuk membangun aksi kolektif lokal dalam pengelolaan kawasan lindung SWP DAS Arau, Sumatera Barat. Jurnal Manajemen Hutan Tropika 18(1):18-30. http://dx.doi.org/10.7226/ jtfm.18.1.18.

Pacheco P et al. 2011. Landscape transformation in tropical Latin America: assessing trends and policy implications for REDD+. Forests 2011 (2):1-29.

Petkova E, Larson A, Pacheco P. 2010. Forest governance, decentralization and REDD+ in Latin America. Forests 2010(1):250-254.http://dx.doi.org/10.3390/f1040250.
Purnomo H, Suyamto D, Abdullah L, Irawati RH. 2012. REDD+ actor analysis and political mapping: an Indonesian case study. International Forestry Review 14(1):74-89. http://dx.doi.org/10.1505/1465548127 99973208 .

Strayer DL, Dudgeon D. 2010. Freshwater biodiversity conservation: recent progress and future challenges. Journal of the North American Benthological Society 29(1):344-358.

Sundawati L, Sanudin. 2009. Stakeholder analysis on ecosystem restoration of Lake Toba catchment area. Jurnal Manajemen Hutan Tropika 15(3):102-108.

Tefera B, Stroosnijder L. 2007. Integrated watershed management: a planning methodology for construction of new dams in Ethiopia. Journal of Lakes \& Reservoirs: Research \& Management 12 (4): 247-259. http://dx.doi.org/10.1111/j.1440-1770.2007.00340.x.

Tomaselli MF, Hajjar R. 2011. Promoting community forestry enterprises in national REDD+ strategies: a business approach. Forest 2:283-300. http://dx.doi.org/ $\underline{10.3390 / \mathrm{f} 2010283 .}$.

Toni F. 2011. Decentralization and REDD+ in Brazil. Forests 2011(2):66-85.

Van Dam C. 2011. Indigenous territories and REDD in Latin America: opportunity or threat? Forest 2:394-414. http://dx.doi.org/10.3390/f2010394.

Wani SP et al. 2006. Farmer-participatory integrated watershed management: Adarsha Watershed, Kothapally India-an innovative and upscalable approach. ICRISAT. SAT eJournal2(1):1-26. 